〈パネルディスカッション〉

\title{
ウクライナ危機をめぐる国際関係
}

\author{
司会・志摩園子 （昭和女子大学） \\ パネリスト・廣瀬陽子（慶應義塾大学） \\ ・六鹿茂夫 (静岡県立大学) \\ -大西富士夫（日本大学） \\ -兵頭慎治（防衛研究所）
}

$<$ Panel Discussion $>$

\section{The Crisis in Ukraine and International Relations}

\author{
Moderator: SHIMA, Sonoko \\ (Showa Women's University) \\ Panelists: Hirose, Yoko \\ (Keio University) \\ MutsushiKA, Shigeo (University of Shizuoka) \\ OHNIsHI, Fujio \\ (Nihon University) \\ HYodo, Shinji \\ (The National Institute for Defense Studies)
}

志摩園子（昭和女子大学） それでは, 午後 の第 2 セッョン，パネルディスカッション を始めたいと思います。「ウクライナ危機を めぐる国際関係」といらことで, 第 1 セッショ ンでは，主にウクライナを中心に括話をして いただきましたが，第 2 セッョンのパネル ディスカッションでは 4 人の先生方に, それ に関連する，少し広域なところに視点を当て た発表をしていただきます。早速，廣瀬先生 のほうから,「ウクライナ危機とロシアー グルジア紛争との比較を中心に—」」と題し て，拈話を始めていただきます。それでは廣 瀬先生，お願い致します。

廣瀬陽子（慶應義塾大学）廣瀬陽子と申し ます。ウクライナ危機そのものにつきまして は, 既に第 1 セッションのほうで詳しく拈話 がありましたので，特に私から申し上げるこ とはありません。
先ほど, 上野俊彦先生（上智大学）が言及 された，2008年のグルジア紛争と今回のウ クライナ危機の関係性については, メディア などでもかなり取り沙汰されて招り，いろい ろな類似点斥指摘されております。しかし， 本当にそれを同じものと考光ていいのかどら かといらことは，かなり疑問が持たれるとこ ろです。

ご存じのように, ウクライナ危機はまだ続 いて扣りますウクライナ危機一つを見ても， クリミア編入と東部の混乱ではロシアの介入 の仕方がかなり違っているため, 十把ひとか らげにウクライナ危機とグルジア紛争の動き を比較することは，非常に無謀なことだとは 重々承知して和ります。そのため, 本報告は あくまでも試論にすぎませんが，問題提起的 な意味合いを持たせる意味でも, 強引に進め させていただきたいと思います。

お手元のあるレジュメに沿う形で拈話をし 
ていきたいと思います。まず二国の事例の共 通点と相違点を洗い出してみました。共通点 として，これは確実に言えると思いますが， グルジアとウクライナの政治的なプロセスと 方向性があります。グルジアについては「バ ラ革命」, ウクライナについては「オレンジ革 命」という，いわゆる「カラー革命」をとも に経験しました。もちろん少数派はそれに反 発しているわけですが，国の多数派が親欧米 路線を取り，EU抢よびNATOへの加盟を目 指すという点では共通していると思います。

第二に, ウクライナとグルジアは黒海沿岸 国であるといら共通点もあります。やはり黒 海といらのは，ロシアにとっては不凍港とし ての魅力がありますので, NATO を牽制でき る軍事基地を維持したいロシアの思惑は間違 いなくあったと思います。

ウクライナには黒海艦隊がありましたし, グルジアは 2008 年に, グルジア本土に設け ていた軍基地をすべて撤去しなければならな くなった状況で，またその頃， ウクライナの ユーシチェンコ政権下では黒海艦隊の維持に 危機感があったことからも，アブハジアを新 たな軍事拠点として維持しょうとした試みが あったのではないかと考えて扣ります。

第三に，旧ソ連に対する欧米の影響力拡大 の趨勢があります。特に 2008 年 4 月, NATO がグルジア， ウクライナに対し，加盟行動計 画，いわゆる MAPを適用しょうという動き を示しました。そして，それがグルジア紛争 の一因になったことは間違いありません。

他方ウクライナでも，2013 年 11 月に $\mathrm{EU}$ の連合条約の署名問題がありました。ただ， NATO は， 2008 年当時も現在もウクライナ, グルジアを加盟させる用意はなく, 空約束で あったといらことは，NATO の前事務総長が 認めているところです。NATO としては，事 実無根の加盟可能性をロシアに見せつけるこ とで，欧米の一体性をアピールしょうとした ようですが, 当然ロシアがその動きに反発し,
後の動きにつながっていったというらうに分 析できます。

第四に，ロシアの「自国民保護」の論理で す。グルジアのときには, アブハジア，南才 セチアの住民の約 90 パーセントがロシアの パスポートを保有して扬りしたし，またク リミアについて言えば，ロシア人の比率が過 半数だということで，ロシア系住民の保護を 名目にした形で介入を図ったという経緯があ ります。

第五に，ロシアが事前準備をしていたとい らこと，直前に軍事演習をしていたこと，自 警団の利用，また武力行使の戦略などがあり ます。グルジア紛争については，2004 年か ら準備をしていたといわれています。2004 年といらのは, 当時のサーカシュヴィリ大統 領がグルジアの主権が実質的に及んでいな かったアジャリアを取り戻したときでした。 そのとき，ロシアのグルジア介入への準備は 始まり，2008 年 4 月からは NATO の動きを 受け，集中的に準備が始められたと考えられ ます。

7 月には, 「コーカサス 2008」といら大規 模な軍事演習を実施しました。ロシアは，軍 事演習とグルジア紛争との関係を否定してい ますが，演習があったということは事実であ り，また，事前に，地元の自警団と称する口 シア軍人が，南オセチアで活動していたこと も確認されて抢ります。そして，8月8日に はロシア第 58 軍と空挺部隊が, 公に南オセ チアに侵攻するといらことになりました。

また，ウクライナについて言えば，これは 諸説ありますが，やはり事前に準備がされて いたといわれています。オレンジ革命があっ た 2004 年からといら説と, 第一次ガス紛争 があった 2006 年からといら説と, また NATO の問題が掲げられた 2008 年といら説 がありますが，ともあれクリミア編入と東部 への影響力拡大への動きが開始され, 政治家, 官僚, 学者, 広報担当者, 政治技術者などを 
投入して，クリミアの世論調査，市民の意識 変革，政治家の親ロシア派などへのすげ替え などが実行されたといわれています。これは 宇山智彦先生（北海道大学）のご論考にもあ りますし，私が今年 8 月にウクライナで調査 したときにも，このような情報を多方面で確 認しました。

そして，2014年 2 月から集中的に準備を 行ったと考光られます。クリミアに実質的な 軍を投入する直前の 26 日，ロシア，ウクラ イナ国境沿いの西部軍管区で大規模な軍事演 習が行われて打ります。そして, 翌27日に 主要な建物, 空港などの占拠が始まりました。

クリミアでも東部ウクライナでも, 「地元 の自警団」なる武装集団が活動しました。ク リミアについては, 後にプーチンが, ロシア の特殊部隊であったと認めていますし, ウク ライナ東部についても 8 月末からは, ロシア 軍が明確に入っていくといら形で, 後には次 第にロシアの介入が明確になっていくわけで すが，少なくとも最初のらちは「自警団」と いら言葉が使われました。またクリミアにつ いては,クリミアからの要請を受けてやった といらことを強調しています。

そして第六に，両国ともにロシアの経済的 圧力にさらされていたといらことがありま す。グルジアについては，2006年に関係悪 化がピークとなり, ガス供給停止, 交通輸送 網の停止, グルジア産品の輸入禁止, 数百人 の出稼ぎグルジア人の強制送還などが行われ ました。

また， ウクライナについては，もちろんウ クライナのガス代金の未払いといら問題はあ るにせよ, 2006 年, 2009 年にはガス供給が 停止され，2008 年はぎりぎりで回避された といらょうな「ガス紛争」がありましたし, 2013 年には, 多くのウクライナ生産品の輸 入が禁止されています。

第七に, 諸外国の事実上の容認があったの ではないかということです。これは, ウクラ
イナ東部については全く当てはまらず，クリ ミア編入と，ロシアによるグルジアのアブハ ジアおよび南オセチアの国家承認のみについ ていえることですが，国際社会は口頭では口 シアを激しく批判しつつも, 実際の制裁は極 めて軽微だったことから，事実上の「容認」 があったように思われます。

第八に, グルジア, ウクライナ側の動きで す。両国は, 南才セチア, アブハジア，そし てクリミアを必ず奪還すると強く主張してお りますが，それでも，まずは自国の再建を優 先して, それらの奪還は後回しにしています。 一見, ロシアの行為を容認し, 諦めたように 見光ますが，実際は，必ず後で奪還するつも りでいます。

最後にクエスチョンマークが付いています が, メディアでは, 両方ともオリンピックの 時期と絡んでいたといらことが散々指摘され ています。つまり, グルジア紛争は, 北京五 輪の際に発生, ウクライナ危機はソチ五輪の ときだったといらことで，メディアではよく 共通点として論じられていますが，私は，む しろ違いではないかと考えています。

といらのは, 参加国と開催国では, 同じオ リンピックでも全く状況が異なるからです。 北京五輪のときは招客さんでしたが, ソチ五 輪はプーチンの肝入りで誘致されたイベント ですので, ウクライナの危機はむしろ輝かし いオリンピックの開催に水を差されたと考え るべきではないかと思っています。

続いて，相違点を考岳すすこちらは，口 シアを主体として考えた場合の違いの多さが 目立ちます。第一に, 2008 年と今年ではプー チンの支持率が全く異なります。プーチンは 2008 年当時には, 85 パーセントという高い 支持率をマークしていましたが, 大統領再就 任直前の反プーチンデモが激しくなった時期 には, 約 55 パーセント, その後も 60 パーセ ント程度を推移していました。ソチ五輪の頃 には若干上がりましたが, 支持率低迷の打開 
策が必要だったといらふらにも考兄られま す。実際に, クリミア編入後に支持率は最高 87 パーセントまで上昇し, 今のところは高 水準を維持しています。

第二にロシアにとって， ウクライナとグル ジアの重要性が格段に違うということがあり ます。ウクライナ・グルジアの両国の国家規 模, 軍隊のレベルの違いに加え, ロシアとウ クライナの民族，言語，文化，歴史的な近さ， これは先ほどの,下斗米伸夫先生（法政大学） の扔話でも十分にご理解いただけたと思いま す。そのような近さ, 地政学的な位置などか ら, やはりウクライナにより多くのコミット メントをするということは当然のことだと思 います。

第三に, 一番大きな違い, すなわち領土編 入の有無です。グルジア紛争では, アブハジ ア，南オ七チアを国家承認して，ロシアの息 のかかったベネズエラなどの他の 4 カ国も追 従させたわけですが，それまでも，アブハジ ア，南オ七チアには，グルジアの主権が及ん でいなかったわけですから，ある意味では現 状追認とも言えます。

しかしクリミアについては, 新たな動きで 編入を実施し， ウクライナの主権を侵害した という点で全く違います。また，第八点目で 敃話しますが，ハイブリッド戦争を含む新し いアクションがいろいらと見られました。そ して, 現地の緊迫度も異なっています。現地 といらのは, 南オセチアとクリミアの違いで す。ロシアはどちらのケースでも，ロシア系 住民が脅威に直面しているといら理由で介入 を正当化したわけですが，確かに南オ七チア がグルジアの脅威に直面していたということ は，ある程度事実だといえます。しかし，ク リミア東部, ウクライナが脅威に直面してい たとは言い難く, 確かにウクライナ暫定政権 が一時ロシア語の使用を脅かすよらな動きを 見せましたが，それがすぐ撤回されたという ことは, 先ほど末澤恵美先生（平成国際大学）
が抒っしゃったと招りです。

第五に, 政権交代の有無です。グルジア紛 争では，それによって政権が脅かされること はなく, 少なくとも短期的には, その後のサー カシュヴィリ政権の支持は上がりました。し かし，ウクライナではヤヌコヴィッチが失脚 したといら事実があります。

第六に, ロシアの軍事力での自信度が 2008 年よりも上がっているということが指 摘できると思います。グルジア紛争で，ロシ アは辛くも軍事的に勝利しましたが，それに よって軍の装備や軍人の質の低さを知りまし た。逆に諸外国は, ロシアの意外な弱さに驚 きました。それを受けて，ロシアは軍事予算 を拡大し, 装備の近代化や精鋭部隊の創設な ぞ，より軍事力を充実させたといら経緯があ ります。実際にクリミアに送られた軍は, 精 鋭部隊だったといわれています。

第七に, ロシアのウクライナに対する軍事 的介入の否定です。ロシアは, これは義勇軍, 地元の自警団によるものだったとずっと言っ ていたわけです。グルジアについては明確に 介入した一方，ウクライナについては，なる べく自分たちの関与を隠すような動きが見ら れます。ただしクリミアについては，4月 17 日にプーチン自身が認めて扣りますし, 東部 の 8 月末の侵攻についても, 現在はロシアの 関与が明らかになっているところです。

第八に，ロシアが新しい戦法を採ってきた といらことです。これは，NATOが言うとこ ろのハイブリッド戦争です。ハイブリッド戦 争とはどらいうものかというと, 標識を付け ない特殊部隊や民兵を送り込んで展開し，官 庁などの要所を占拠して，大規模な正規軍を 国境付近に集積して圧力をかけながら, 宣伝 戦やサイバー攻撃, 経済的強迫, 時に融和的 な外交などあらゆる手段を組み合わせて，住 民投票や一方的独立, 領土併合や地域の不安 定化などを実現するというものです。その戦 法については, 現在, NATO が詳細な検討を 
進めているところだと聞いています。

第九に, グルジア紛争からの学習の事実が あります。グルジア紛争の後, 実は, 諸外国 の動きはロシアにはあまり冷たくはありませ んでした。特にヨーロッパは, ロシアへの気 遣いをかなり見せました。そしてアメリカも， 一時は反発していましたが，才バマ政権が誕 生した途端に「リセット」が提案されるなど, グルジア紛争を通して，「かなり乱暴なこと をしても国際的に容認されるのではないか」 ということをロシアは経験してしまったよう に思います。ですから，欧米のグルジア紛争 に対する間違った対口政策が，ウクライナの 悲劇を引き起こしたという説もあります。

第十に, 旧ソ連諸国の反応の違いです。グ ルジア紛争の際には, すべての旧ソ連諸国に 加えて, 上海協力機構などの親口的な国が沈 黙を保ち，グルジアの武力行使を批判するに とどまった一方，今回のクリミア編入につい ては,アルメニア， ベラルーシが賛成を示し たといら経緯があります。旧ソ連諸国による ロシアの動きの承認の有無は，かなり大きな 違いだと考皃ます。

第十一に，ロシアとの関係悪化による影響 の違いです。これはウクライナ, グルジアの 視点に立っての話ですが，ロシアとの関係が 悪化した場合に受ける衝撃は, やはりウクラ イナのほうが格段に大きいです。なぜなら， ロシアへのエネルギー依存度や経済的な関係 が深いからです。グルジアは，仮にロシアか ら制裁されても，たとえばエネルギーはアゼ ルバイジャンから輸入できますし, 近隣諸国 との関係強化によって比較的早期に経済の立 て直しができたといら経緯があります。しか し, ウクライナは, ヨーロッパに頼っていく しかないという事情があります。

第十二に，名目的になりますが，NATOの 態度の違いもあると思います。2008 年のグ ルジア紛争のときには，NATO はかなり腰が 引けてしまい，同年 4 月には MAP の適用す
らちらつかせていたのに， ウクライナに対し ても,グルジアに対しても, その問題を白紙 にするということがありました。しかし， 「ポーズである」とは言われていますが，最 近はグルジアへの接近を強めるなど，NATO のコミットメントが高まっているように思い ます。

共通点, 相違点は以上ですが, その一方で, グルジア紛争のみならずウクライナ危機を, 過去の別の事件と比較して考えるといらこと も興味深いのではないかと思います。たとえ ばクリミア編入は，ナチスのズデーテン地方 の編入と似ているといわれています。また東 部の混乱は, ソ連のアフガニスタン侵攻や沿 ドニエストルの経緯に似ているとも考兄られ ます。

アフガニスタン侵攻は私の専門ではないの で，立派なことは申し上げられませんが，ア フガニスタンの問題は, ソ連がアメリカの勢 力の拡大を恐れた上で, 兵を送り込んだ結果, それが実質的な戦争になった点は似ていま す。そしてアフガニスタン侵攻でソ連が決定 的に悪者となった契機は大韓航空機丞落事件 でしたが，ウクライナ危機に扮けるマレーシ ア機撃墜事件との類似性の指摘もよくされて います。な拉，アフガニスタン侵攻と東部の 危機の類似性はウクライナの研究者がよく指 摘しているところです。

次に, 沿ドニエストルの紛争については, 実際に主導した人物，たとえば，「雇われ」 とはいえ，ストレリコフなどが共通していた り，もともと自治共和国であった歴史がない のに，ともに作られた共同体であるというこ とが挙げられると思います。

このように見てきて, 現状でのまとめに入 りたいと思います。グルジア紛争， ウクライ ナ危機に対するロシアの関与で, ともに共通 する要素は確かにあります。しかし，その一 方で，大きな違いもたくさんあったといらこ とが言えると思います。このように，グルジ 
ア，ウクライナの動きを分析するには，それ らの両国とロシアのみの検討だけでは不十分 であり, 国際社会の関わり方, 歴史的文脈に おける検討など, bっと長期的, かつ広いパー スペクティブに立った多面的な分析が必要不 可欠であると感じます。研究報告というょり, ほとんど問題提起となってしまいましたが, これで終わります。ご清聴ありがとらござい ました。

志摩 続きまして六鹿先生より,「ウクライ ナ危機と広域ヨーロッパ国際政治」というこ とで扣話をいただきます。

六鹿茂夫（静岡県立大学）六鹿です。どう ぞよろしく㹉願いします。この写真は，昨年 11月末, 東方パートナーシップ・サミットと 並行して，ヴィリニュスで開催された市民社 会フォーラムのウクライナ・セッションです。 ヤヌコヴィッチの帰国後, ウクライナ危機が 深まっていき，ヴィリニュス・サミットから 扎よそ三カ月後に，この会議に出席していた ポロシェンコ, ヤツェニュークら野党指導者 達が政権を握ることになります。ウクライナ 危機につきましては, 第 1 部で議論されまし たが，私の報告では，それを広域ヨーロッパ の観点から考察したいと思います。具体的に は, 冷戦後の欧州国際秩序とロシア問題, プー チン政権の外交・安全保障政策，国際社会の 対応 (和平交渉を中心とした), 欧州国際秩序 への影響の四つを中心に進めてまいります。

第一は, 冷戦後の欧州国際秩序とロシア問 題ですが，私は，ウクライナ危機の遠因は， 1989 年 11 月 9 日のベルリンの壁崩壞まで遡 ると考兵ます。冷戦後の欧州国際秩序の原型 は，翌年 10 月 3 日までの約 1 年間の諸大国 間交渉に招いて出来上がりましたが，それは EU と NATOを中心としたもので，ゴルバ チョフが主張した CSCEを中心とする集団 安全保障体制は排除されました。ゴルバチョ
フは，ワルシャワ条約機構と NATO を政治 化していき，ゆゆくはCSCEを中心とし た集団安全保障体制を構築することで, 冷戦 後に扮けるソ連の発言力や影響力を残そうと 考えていました。しかし，同構想が却下され たことで，その後のロシアは，ご存じのと㧤 り, NATO との間ではNATO・ロシア理事会 を通じて，EUとの間では「四つの共通空間」 や「近代化パートナーシップ」を通じて関係 を持つにとどまり，ロシアは欧州国際政治の 中心から締め出され, 潜在的な修正主義国家 になったのです。

ウクライナ危機の第二の原因は，バルト海 から黒海に至る諸大国の「狭間の地政学」を めぐる国際政治の連続性です。19 世紀は 4 帝国が同地を分割支配し，第一次世界大戦後 は, 諸大国が権力闘争を続けた結果第二次世 界大戦へと至り, 戦後この地域に「鉄のカー テン」が敷かれて，欧州は東西に分断されま した。しかし，1989年の東欧革命と 91 年の ソ連邦の崩壊によって, この狭間の地域に, 再び力の真空状態ないし安全保障の真空状態 ができ，それを埋めたのは，歴史的な法則に 則って力の強いもの, つまり EUと NATO でした。その結果, 2004 年の EUと NATO の拡大後, 欧米とロシアが, 新しい力の真空 地帯である旧ソ連の西部地域と南コーカサス をめぐって権力闘争を展開し，2008年の口 シア・グルジア戦争, 本年のウクライナ危機 に至ったわけです。

ウクライナ危機の第三の原因として, 非連 続性にも注目する必要があります。EUと NATO は，かつてのように東欧諸国民の意思 に反して，軍事力を用いてこの地を占領した のではなく，民主化等々のコンディショナリ ティーを課し，それらを満たした国から EU やNATO に加盟させていきました。つまり， 価值の輸出です。

ウクライナ国内には, EU や NATO への加 盟を望む人もいますし，それに反対する人も 
いますので，この価值をめぐって国内で対立 が生じるわけです。しかし，その対立はウク ライナ国内にとどまらないで，国境を超え， ロシア国内の価值をめぐる対立に影響を及ぼ していきます。その結果, 民主主義という価 值をめぐって, ウクライナとロシアの間に, トランスナショナルな対立と協力の構造が出 来上がるのです。

そこで，マイダン革命が起きると，プーチ ン大統領はヤヌコヴィッチを介してそれに介 入していくわけですが，マイダン革命の成功 により敗者となった彼は, 場所をクリミアに 移して闘争を展開し，クリミアを奪取するこ とでおよそ 90 パーセントの国民の支持を得 ることに成功したのです。ここに㧤いて，彼 はマイダンの敗者からッァーリの地位へと上 り詰めたのです。

しかし，プーチン大統領の目的は, 政権の 維持だけではありません。地政学的な構想 が, もら一つの重大な目的として設定されて います。大欧州 (Большая Еврора, Greater Europe）です。これは，EUと，やがて創設 されるであららユーラシア連合を，時間をか けて統合していき，最終的に大欧州を構築す るという構想で, ロシアの政治エリートはこ れによって中国やアメリカに対抗できると強 調します。同構想はエリッィン時代から唱え られていましたが，プーチン政権の主要な目 標は，大欧州ではなく，むしろユーラシア連 合の創設にあります。CIS 自由貿易協定で十 分なはずなのに, わざわざ EUが掲げる自由 貿易圈（DCFTA）と両立しない関税同盟を つくり，ウクライナ側に加盟するょう迫った のはそのためです。

しかし，クリミアを奪取しただけでは，ウ クライナ全体をロシア勢力圈に留めることは 扣よそ不可能です。そこで, プーチン大統領 は, ウクライナを連邦化し, 外交問題に関す る拒否権など強大な権限を持つ共和国を東部 につくることで, ウクライナの EU や NATO
への接近を阻むべく，4月 6 日から 7 日に掛 けウクライナ東部で武装闘争を開始したので す。これは，まさに，2003 年 11 月にトラン スニストリア（沿ドニエストル）問題解決モ デルとして公表された，コザック・メモラン ダムに則った方式そのものです。

しかし，それでも万が一，ウクライナが NATO に接近するような場合, NATO に入る ウクライナを弱小化すべきとの発想は，権力 政治ではよくある戦略かと思われます。そこ で，プーチン政権は，ウクライナを分割し， ノヴォロシアを独立させて緩衝国にすると か, ロシアに併合して自国領土をドナウ川流 域まで拡大するといった, 諸々の構想を準備 していたものと推量されます。そして，それ らの中で最も穏便で成功率の高い選択肢が, 東部のトランスニストリア化であったといら ことです。

では，こらいったウクライナ危機に対し， 国際社会はどのように対応したのでしょう か。冷戦後の安全保障体制は, NATO, EU, OSCE, 欧洲評議会 (Council of Europe) か らなる重層的（インターロッキング）な構造 だと言われます。つまり, これら諸機構が, 相互補完的な役割を果たしながら, 冷戦後の 安全保障体制を維持してきたわけです。グル ジア・ロシア戦争はあまりにも短かったため, この安全保障体制は機能しませんでしたが, 今回は半年かけて，それぞれの機構が競合し ながらも相互補完的に役割りを果たしたと言 えましょら。

和平交渉への関与も国際社会の重要な役割 りの一つですが, 最初にイニシアティブを 取ったのは, アメリカとEUによる 4 月 17 日のジュネーヴ交渉でした。そして, 同交渉 が破綻すると，即座に OSCEがロードマッ プを作成し，OSCE にロシアとウクライナを 加えたコンタクトグループを作りました。6 月 20 日に公表されたポロシェンコ和平案も, このコンタクト・グループを中心に交渉が進 
められました。

ここで注目すべきは，ポロシェンコ氏は非 合法な武装勢力とは絶対に交渉しないと明言 していましたが，6月23日のドネック交渉に は，コンタクト・グループに加え，ルガンス クとドネックの代表と, プーチン氏が推した と言われる親ロシア派ウクライナ人政治家ま で入っていました。このような交渉枠組みは, ロシアの圧力だけでは実現しなかったでしょ ら。恐らく，ドイッの圧力が働いたものと推 量されます。その証拠に，ポロシェンコ氏が 7 月 1 日に停戦を打ち切って東部での攻撃を 再開すると，翌日ベルリン 4 力国外相会議が 開かれ，即時停戦と7月5日でのコンタク ト・グループ会議の開催が決定されたのです。 この時点での停戦は, 武装勢力による東部地 域の占領を事実上承認し，その上で停戦交渉 に応じることを意味しますから，明らかにト ランスニストリア化への道，すなおち， ウク ライナ東部の未承認国家化への道が開かれる わけで，それを推進したのがロシアとドイッ であったといらことです。つまり，この時点 では独露協調がカギを握っていたのです。

その後は, 9 月 3 日のプーチン氏の和平イ ニシアティヴ，9月 5 日のミンスク和平協定 へと続くわけですが，プーチン大統領が和平 イニシアティヴをとったのは，ウクライナが 10 月の議会選挙をかなり早い時期に決定し たからではないでしょらか。議会選挙が行わ れれば, 当然, 新欧米派がウクライナ議会の 過半数を占めるでしょらから，ロシアとして は，議会選前に東部問題についてロシアに有 利な道筋をつけて拈く必要性が出てきたから です。勿論, NATOウェールズ・サミットが 9 月 4 日に控えていたことや, EUが 7 月 30 日から 31 日にかけて制裁を第 3 段階に引き 上げたことが，重要な要因として働いたこと は疑いありません。

他方，ウクライナが和平案を受諾した一番 大きな理由は，同国が最早戦闘を続けられる
ような状況になかったことです。一つは，ウ クライナ側に多くの犠牲者が出たためであ り, もら一つは, ポロシェンコ氏がワシント ンに赴いた際，オバマ氏がウクライナへの武 器供与を断ったことです。NATOもドイッも, ウクライナへの武器供与に同意しませんでし た。さらに, ポロシェンコ大統領は, 非 NATO 加盟国であるウクライナへの同盟国と しての地位供与も要請しましたが，オバマ大 統領はこれも拒否しました。ポロシェンコ氏 の「西側も和平を望んでいる」との発言は, このよらな状況を言い表したものと推量され ますが，欧米国際社会によるウクライナに対 する停戦圧力が, ウクライナに和平案を受諾 させた一つの要因であったと考えられます。

最後の第四の問題, ウクライナ危機の影響 については，時間の関係上，冒頭で申し上げ ました三点のらち二つと, 黒海国際政治への 影響について述べたいと思います。第一に, ロシアは再三にわたり, 冷戦後の欧州国際秩 序の集団安全保障体制化を提唱してきました が，今回のウクライナ危機により NATO が 集団防衛体制の強化に向かいましたので，集 団安保体制への道はさらに遠のくでしょう。

第二の「狭間の地政学」をめぐる権力闘争 に関しては，DCFTAをめぐる対立が注目さ れます。ロシアは，DCFTAが自国経済に否 定的な影響を及ぼすとして，大幅な修正を求 めました。そこで，EUが仲介に入り，EU， ロシア，ウクライナの間で話し合いが行われ た結果，DCFTAの履行を 2015 年 12 月末ま で延期することと，ロシアが停止するとして いた CIS 自由貿易協定をウクライナに継続 して適応することで合意が得られました。

この交渉で勝利したのがロシアなのか EU なのかについてはいろいろな評価があります が，DCFTAの履行が 1 年少々延期されただ けですので，これをめぐる対立はこれからも 続いていくものと思われます。興味深いのは, $\mathrm{EU}$ 拡大担当のステファン・フューレ氏が, 
DCFTA の履行延期は，よく言われるように ロシアによる圧力ではなく, ウクライナの要 求によるものであり, ウクライナの現在の経 済状況はDCFTA を履行できる状況にないと 語ったことです。

ウクライナ危機の影響に関してもら一点留 意すべきは，関税同盟への影響です。5月末 に関税同盟からユーラシア経済連合へと向か ら協定が結ばれたと記憶していますが，カザ フスタンが領土保全に固執したため, 交渉は かなり難航したと言われています。アルメニ アの加盟に関して，ナゴルノ・カラバフを切 り離すよう求めたとのことです。ロシア系住 民が多く住むカザフスタン北部の領土保全 が，念頭にあっての発言と推量されます。

最後に, ウクライナ危機の黒海国際政治へ の影響について一言だけ言及して終わりたい と思います。黒海は1997 年あたりからロシ アとトルコの海でした。ロシアとトルコは協 力して, 黒海が EU や NATO の海になるこ とを防いできたのです。ところが，ロシアが クリミアを領有したことで， ロシア黒海艦隊 が著しく増強されることにでもなれば，黒海 はロシアとトルコの海からロシアの海へと変 貌を遂げていくことになります。また, 最近, トルコとロシアは，欧州通常兵力削減条約 (CFE), ミサイル防衛, シリア問題などをめ ぐって対立を深めていましたが，ロシアのク リミア領有により，新たにクリミア・タター ル問題も台頭してきました。黒海国際関係は, 今後, 軍事バランスの問題以外にも様々な課 題を抱えながら，展開されていくことになる でしょう。時間になりました。ご清聴ありが とらございました。

志摩 ありがとうございました。続きまして 大西先生より,「ウクライナ危機後の北極国 際政治」ということで括話を伺います。それ では，よろしく打願い致します。
大西富士夫（日本大学）日本大学国際関係 学部の大西と申します。ウクライナ危機をめ ぐる国際関係といらことで, 私が一番関心が あるのは，ロシアが現状維持なのか，それと も修正主義の外交に転じたのかといらことで す。ちょらど『フォーリンアフェアーズ』で, 今年の各号でそらいら賛否両論が起きていま す。今回，共通論題のテーマを作ってくださ いました六鹿先生も書かれていますように, ロシアは，2008 年のグルジア紛争辺りから， 現状変更政策に転じたと見ることもできるよ らです。

実際にロシアがぞう考えているかといらこ とを，いかに評価するかといら問題は，私が 研究している北極圈に関係してくるものであ り, 国際政治全般にも大きな影響があります。 私の報告は，北極の国際政治に対して，ウ クライナ危機の影響があるのかどらかといら ことについての考察です。いろいろな論じ方 があると思いますが，私は，北極国際政治の 基本的な構造への影響を考えます。最初の論 点として, 北極国際政治の基本的構造とは何 かを明らかにします。ここでいら基本的構造 には二つあり，世界政治と北極の地域的な連 動性 (連続的連動性と突発的連動性), それ と, 北極地域「内部」の国際的なダイナミク ス (域内政治力学) です。第二の論点として, これら二つの北極国際政治の基本的構造を踏 まえた上で，現在，特にクリミア編入前，す なわち，2014 年 3 月までの北極国際政治は ぞらいら状態だったのかといらことについて も述べさせていただきます。第三の論点とし て, 特に 3 月以降, クリミア編入の一連の動 きが明らかになった後, 北極国際政治の基本 的構造にはどらいう影響があったのかという ことについて述べます。

タイトルも,「ウクライナ危機後」という 表現が適切かどうか迷いました。北極の国際 関係研究者の間でウクライナ危機の問題がよ く論じられるようになったのが， 3 月のクリ 
ミア編入の後でした。3月は一つの大きな ターニングポイントだといら意味で,「ウク ライナ危機後」というタイトルを掲げました。 扮手元の資料は，字が小さくて恐縮です。 まず最初の論点ですが，「北極国際政治の基 本的構造」というところをご覧ください。ま ず，（1）世界政治と地域政治の連動性という ところを見ていきます。北極と国際政治がど のようにつながっているのかといらと, 繰り 返しのリンクの仕方，パターン化されている ものと突発的なつながり方の二つがありま す。連続性を含んでいるものとしては，国際 政治全体の国際的緊張が低下寸ると，北極地 域で地域協力が発達してくるといらことがあ ります。

時間の関係でこれについては詳しく述べら れませんが，そこに，北極地域での，第二次 世界大戦の最中から冷戦期を通して，いろい ろな構想が載っています。たとえば，第二次 世界大戦末期には，ルーズベルト政権のとき のアメリカ副大統領の北極条約構想や, 冷戦 末期には，ゴルバチョフのムルマンスク演説 の中で北極圈協力といらものも出ました。

これらは実現されなかった構想です。実現 された構想には, 1973 年に調印されたホッ キョクグマ保全条約があります。これは, ホッ キョクグマの保全管理をらたったものです。 それ以外では, 非政府間協力ではありますが, 国際北極科学委員会，また，フィンランドが イニチアチブを取った北極環境保護戦略 (AEPS) などがあります。ノルウェーがイ ニシアチブを発揮して始めたものにはバレン ッ・ユーロ北極評議会（BEAC）もあります。 また, カナダがイニシアチブを発揮した北極 評議会などもあります。実現されたものを見 ると、これらは緊張が低下したときに調印さ れています。ホッキョクグマ保全条約の場合 はデタントで，それ以外は冷戦終結後の時期 に当たります。

では，突発的な関連性，北極で地域協力が
行われやすくなった国際的な要因は何だった のかといらと, 当時は安全保障概念が多様化 していたといらことがあると思います。軍事 問題や環境，人的な側面の安全保障なぞ，い ろいろと多様化していく国際環境の中で，北 極に掞いても地域協力が開始しやすくなった といらことです。

また，冷戦終結により，二極からアメリカ 一極になっていく中で，特にカナダ，フィン ランド，ノルウェーなどの中小国が，国際的 な行動, イニシアチブを取りやすくなってい たといらこともあります。それが，実現され た地域協力のほとんどが，90年代に出てき たことの理由です。

次に，（2）の，北極内の政治力学をご覧下 さい。重要な政治課題になったものは, 二点 あります。一つは，どの国が北極諸国に含ま れるかといらことです。これはメンバーシッ プの問題です。アークティック・ファイブは, 北極海に面する国々，アメリカ，ロシア，力 ナダ，デンマーク，ノルウェーの 5 カ国です。 それとは別に，アークティック・エイトは， 今申し上げた 5 カ国に, 北極海には直接面し ていない, スウェーデン，フィンランド，ア イスランドを加えたものです。

地域協力の歴史の中には, 北極諸国を 5 力 国にするか 8 カ国にするのかといらメンバー シップをめぐる対立があります。なぜそのよ らなことが起きるかといらと, 南極条約の場 合とは違い, 北極圏に関しては国際的に明確 な取り決めがないからです。南極条約では, 南緯 60 度以南と明確に合意されていますが, 北極の場合にはそらいったものがないのです。

もら一つの地域内の政治力学は, 地域協力 を行うときに，どのようなテーマで協力をす るかといらイシューエリアの問題です。イ シューエリアも, 地域協力やいろいろな構想 を見ていくと, 科学観測, 非核地帯化, 海軍 協力, 特に海軍力の制限, 資源開発, 北極海 航路，環境保護，持続可能な開発など，いろ 
いろな提案がありました。

いろいろな提案がある中で，北極諸国で, 時に 5 カ国であったり，8 カ国であったりと いら変遷はありますが，そこで基本的に合意 されてきた分野は，環境保護と持続可能な開 発の二つのイシューエリアでした。もちろん その二つの合意ができるまでには，いろいろ な駆け引きや交渉，それをめぐる攻防がある といらことです。

環境保護と一口に言っていますが，さまざ まなものが含まれています。そこの星印のと ころに内訳が書いてありますので，ご覧くだ さい（70 年代〜ホッキョクグマ保全管理, 90 年代 污染物質監視・削減, 海洋污染防止, 動植物保全, 緊急事態対応, 2000 年代～航 空海上捜索・救助, 油濁污染準備 - 対応, 気 候変動対応)。北極国際政治の基本的構造の 小括としては, 冷戦終結後の緊張の低下と, 先ほど申し上げた安全保障概念の多様化と いった国際的要因のもとで,アークティック・ エイトのメンバーシップ，すなわち北極諸国 を 8 カ国とすること，そして，2つのイシュー エリア，すなわち環境保護と持続可能な開発 を軸とする北極協調体制が，1990年代に成 立したということです。

二つ目の論点に移りますが, そうしたメカ ニズム, 北極国際政治の基本的な構造から見 て, 現在はどらいう状況かということを㧊話 します。ウクライナ危機発生前, 特に 3 月の クリミア編入前までの状況です。

現在の北極協調体制に対する，二つの大き な政治的挑戦がありました。一つは，アーク ティック・ファイブの復活です。アークティッ ク・ファイブをもら一度, 政治的に求心力の あるものにしようといら動きです。そのよう な話が出てきた背景には, 2007 年, 2012 年に, 著しく海水面積が減少したことがあります。 氷がなくなると, 海底の資源, 航路利用の管 轄権の問題が出てきます。この問題をめぐり, 北極海に面している国々がもら一度自分たち
で話し合い，協議し，国際的な合意をつくろう といら流れの中で出てきた話だったのです。 しかし，結論から言うと，アークティック・ ファイブに対するアメリカの反対によりアー クティック・エイトの枠組みは残りました。

二つ目の挑戦は, 非北極圈諸国の北極圈一 の参入です。氷がなくなることにより, 中国, 韓国, 日本, 皂た EU, イタリア, シンガポー ルなどのいろいろな国が, 北極で, 資源開発, 航路利用などのビジネス参入を考光始めまし た。当然ここには政治も付いてきます。こ れを受けて, 北極国際政治, 現在の協調体制 に扮いて，新しいプレーヤーをどう位置付け るかという問題がにわかに発生してきたので す。

これについては, 現状の協調体制のより所 となる北極評議会といら国際的なフォーラム の中で，彼らにパーマネント・オブザーバー の資格を与えるということで, 非北極圈諸国 と北極諸国は一応合意しました。ただ，懸念 材料はあります。オブザーバーの資格を得た からといって, 非北極圏諸国は満足するのか といらことです。オブザーバーの資格は極め て限られていて，発言権もありません。日本 はまだぞらなるか分かりませんが，その中で 特に中国は，そらいら不満を持ち、アーク ティック・エイトの現状の協調体制に代わる 動きに出るという可能性はあります。

小括としては, 海氷面積が縮小した後, 現 行の北極協調体制に対して，二つの政治的な 挑戦があったが，今現在に至るまでは, 現行 の体制が維持存続されているといらことで 于。

三番目の論点になります。ウクライナ危機 の影響についてです。3月のクリミア編入後 の北極情勢について, 経済, 軍事, 安全保障 分野, それから政治について, 主要なものを レジュメの 2 ページから 3 ページにかけて挙 げさせていただきました。まず，経済分野で は, 欧米の対ロシア制裁, 特にエネルギー分 
野，技術も含めての対ロシア制裁によって, 北極海に扔いて合同で探鉱活動をしていたエ クソン・モービルとロスネフチが一時停止し たと，9月に発表されました。

また，昨年まではいろいろな船籍の船が， ロシアの上の北極海航路を通過していました が，今年はまだロシア船ばかりで，外国船籍 の船が通っていないといらことです。これは 異常なことです。

次に，ローカルな経済についてです。今年 9 月 20 日から 29 日末で, 北海道大学の田畑 伸一郎先生のプロジェクトで，ムルマンスク とアルハンゲリスクを訪問する機会がありま したが，その中で地元の人たちにいらいろな 意見を聞くことができました。そこでは，今 のところ経済制裁の影響で実感できるものは 何もないということでした。

むしろ私が驚いたのは，経済制裁をされて 欧米の技術がロシアの北極海から消えていく なら，自分たちでこれをチャンスと捉えたい と彼らが言っていたことでした。たとえば， アルハンゲリスクの北方 (北極圏) 連邦大学 では，北極海に抢ける資源，航路，港湾に関 わる議論が盛んに行われていました。

ビジネスに携わる人たちの間でも産学連携 を通じて，経済制裁によって発生するであろ ら危機, 将来の不安を乗り越えていこうとい らメンタリティーを非常に強く感じをした。

軍事安全保障，ロシア極北の軍事能力の強 化に関しては，ロシアの閣僚からは様々な発 言が続いています。しかし，これは，3月の ウクライナ問題が起きる前から続いているこ とで，特段目新しいことではありません。ま た, 今年の春にバレンツ海で予定されていた, ロシア，アメリカ，ノルウェー3カ国合同軍 事演習は中止になりました。そして、ムルマ ンスク沖では，アメリカとロシアの海難船救 助合同演習も予定されていましたが，これに もアメリカは不参加でした。

そして，これは少し北極の文脈とは異なり
ますが，ロシア空軍は 8 月末にフィンランド の領空を侵犯し，その直後，フィンランド， スウェーデンが， NATO ウェールズ・サミッ 卜に扮いてNATOとそれぞれホスト・ネー ションサポートを結びました。恐らく，ロシ アの今回の領空侵犯は, NATO とフィンラン ド，スウェーデンの合意に対する牽制だった のだろらと思います。

政治分野での影響はあまり見られず，特に 北極評議会の運営は順調に行われましたが， 一つだけ目立った動きは，例外的ではありま すが，4月のモスクワで開かれた北極評議会 の実務者協議をカナダの代表がボイコットし たといらことです。これからもっと深刻にな ると，いろいろとボイコットが多発すると思 われますが，私が確認できている範囲では， まだ一つだけです。

小括ですが, ウクライナの影響については, 特に経済分野などでは，一定の影響はありま したが，北極協調体制の成立条件を覆すまで の影響までには至っていないといらことです。

全体の結論は二点あります。まず第一点は, 国際的緊張の低下が，現行の北極協調体制成 立の前提条件となっていることからすると， ウクライナ危機が今後さらに深刻化するよう なことがあれば，北極協調体制は機能不全に 陥る可能性があるということです。第二点は， ウクライナ危機の影響は, 現時点において経 済分野では一定の影響があるものの，北極国 際政治の基本的構造を機能不全にしてしま ら，ないしは変更してしまうまでには至って いないといらことです。ありがとうございま した。

志摩 時間のご協力をありがとうございまし た。続きまして兵頭先生より，「ウクライナ 危機とアジア—ロシアの視点から—」で す。よろしく打願いします。兵頭先生のレジュ メは配布されて打りません。パワーポイント のみです。 
兵頭慎治（防衛研究所）ロシア, そしてヨー ロッパ，北極と来て，最後に，私に与えられ たテーマは, ウクライナとアジアについて論 じろといらことです。ウクライナそのものに ついては，私はまったく分かりませんので， あくまでも，ロシアとアジアの関係がウクラ イナ危機以降，ぞら変化しているのかといら 点について，問題提起をさせていただきたい と思います。

ウクライナ問題というのは, ヨーロッパと ロシアのはざまで摇れるウクライナとか, 欧 米とロシアの対立といら構図で説明されがち です。基本的にはとらだと思いますが，ウク ライナ危機にはもっと別の要素, アジア, 特 に中国のファクターはなかったのだろらかと いらことを考えてみたいと思います。そして もら一つ, ウクライナ危機がアジアにどのよ うな影響を与えたのかについても考えてみた いと思います。

アジアといっても広いわけですが，時間も 限られているため，ここでは中国とロシアの 関係，そして日本との関係，これがどういら 意味を持っているのかについて見ていきたい と思います。

まず, 中国とウクライナの関係は, 実は思っ ていた以上に深いということです。まずは, ウクライナから中国への武器輸出の話です。 中国が初めて作った空母，そしてその上に載 せている戦闘機も全部, 何らかの形でウクラ イナから導入したものです。

そして, 日本に一番関係するのは, このホー バークラフト型の世界最大級揚陸艇ズーブル です。この中に戦車 3 両を載せて, 島などの 上陸作戦に使らといらことです。中国が尖閣 諸島で使う可能性があるということで, 岸田 外務大臣が昨年, ウクライナ政府に遺憾の意 を表明しました。

これは, クリミア半島のフェオドーシアと いら造船所で造られています。そして，すで に4 隻が中国に納入されています。ただ，ク
リミアはロシアに編入されましたので，今後 引き続き中国に納入することは難しくなりま した。

最後に，今，大西さんが北極の話をされま したが，これは，北極探査船の雪龍です。こ れで中国は，今，盛んに北極に進出している わけで，今年の夏も 6 回目の北極探査をやっ た砕水船です。これも実はウクライナから導 入しています。

次は, ウクライナの経済進出です。ウクラ イナへのいろいろな形でのインフラ整備, ヤ ヌコヴィッチ政権のときに計画されていた農 地の租借などがあります。これは, 人民解放 軍系の組織により, 日本の農地の 3 分の 2 と いら 300 万ヘクタールの租借計画が進んでい るなど, クリミア半島も含めて, ウクライナ にはかなり中国が経済進出をしていました。 よく調べてみると, 実はこれは, 昨年, 習近 平国家主席が打ち上げた「シルクロード経済 協力ベルト構想」に関連しています。「シル クロード経済協力ベルト構想」とは, 昨年 9 月に習近平国家主席がカザフスタンに行った ときに表明したものです。これは, 中国西部 と中央アジア，そしてウクライナを通るシル クロードをヨーロッパまでつないでいく，そ して，そこに中国が経済的に進出をすること により，そのべルトを使って，発展の遅れた 中国西部をさらに開発するという大プロジェ クトです。この「シルクロード経済協力ベル ト構想」は, 2014 年の 5 月に開かれた中露 首脳会談で話題となりました。

三番目は，ヤヌコヴィッチ前大統領が 2013 年 12 月に中国に行って, 習近平国家主席に 会ったわけですが，そのときは資金援助が目 的であったと言われました。そのとき，「中 国ウクライナ友好協力条約」といら二国間条 約が結ばれました。安全保障面で注目された 文言は，「ウクライナが核の脅威に直面した 際, 中国が相応の安全保障をウクライナに提 供する」といら一文です。 
一部のメディアはこれについて，中国が核 の傘をウクライナに提供すると報じました が，ウクライナがどこから核の脅威を受ける かといらと，それはロシアからしかありませ ん。したがって，この一文はロシアを政治的 に毀損するものであると, ロシアの有識者, 専門家などが指摘しています。

ただ，この背景について，モスクワでいる いろと話を聞いてみると， ウクライナが「ブ タペスト覚書」で核保有を断念した際に，ウ クライナ自身が核の問題に直面したときは, ロシアも含めた核保有国は一定の安全保障を 提供することとなり，これを踏まえて中国も 今回の友好協力条約の中にこの文言を入れた ようです。ただ，この条約が作られたのが 2013 年 12 月といらタイミングだったため, ロシアからすると両国の接近は政治的にかな り気になったよらです。

それから，これは別にロシア自身が公言し ているわけではありませんが，今回のクリミ ア編入の問題など，軍事面で見ると，バルト 三国を除く旧ソ連地域は, ロシアからすれば, 外国の軍事的影響力が及ばない影響圈であっ てほしいと思っています。

ロシアがいつごろからクリミア編入を準備 していたのかといらことが, 先ほどから議論 になっていますが，一つの見方として，ロシ アは，ロシア軍が国外に展開できる国防法の 改正を，グルジア紛争の 1 年後の 2009 年に 行っていることがあります。これによって初 めて, 国内法によって, ロシア軍が自国民保 護等の目的で，この地上部分の影響圈と考え ている旧ソ連地域を念頭に置いた軍事展開の 道を開いたわけです。国外に軍事展開すると きは, 大統領が議会（上院）の同意を取ると いら手続きもその法律の中に含まれていて, 今回はそれを実行したのです。

最近，私が仮説的に思っていることは，先 ほどの大西さんの話ではありませんが，プー チンが再び大統領としてカムバックしてから
のここ数年の間に，ロシアは北極や極東も, 外国の軍事的影響が及ばない影響圏であって ほしいと思い始めているのではないかという ことです。

なぜかといらと, 2012 年 5 月 7 日に, プー チンが大統領として再登板した当日に公布し た軍事に関する大統領令の中で, 北極・極東 の海軍を増強するといら指示を出しました。

そこでは, なぜか北極と極東, 海軍としか 言及されていません。この辺から，なぜ北極 なのかといら疑問がありました。大西さんも 指摘されたように, 去年辺りから, ロシアは, 北極圈の中で軍事プレゼンスの強化を行って います。冷戦時代に閉鎖された空軍基地を再 開する，あるいは，極東でのロシア軍の動き も，北極海航路をにらんだ形で進めていると いら見方が強まっています。

プーチンがなぜ，公的文書やその他の演説 で，北極とオホーツク海を中心とした極東を 並列して言及するかというと, 水に閉ざされ， 地政学的にはほとんど意味がない, 安全保障 上も関心の対象外だった地域に北極海航路が できることにより，北極と極東が航路でつな がるといら発想があるからだと思われます。 そのため, フランッ・ヨーゼフ島で安全保障 会議を開いたり，北極に関する国家文書をこ こ 1,2 年で急速に整備したり, かなり北極に 関心が及んでいます。北極重視の動きは, 表 向きに掲げる政策，戦略，実際のロシア軍の 対外行動からもある程度言えると思います。 そして，これがウクライナ危機以降，強まっ ている感があります。先ほど, 大西さんから も, 今年の夏は, 北極海航路にはロシア国内 船しか通ってないというご指摘もありました。 中国は今年も, 先ほど言ったウクライナか ら買い取った雪龍で，第 6 回目の北極探査を 行いました。これは前回の第 5 回目の探査の 地図です。行きは, ロシア沿岸の北東ルート を通りましたが，帰りは，氷が小さかったた め砕水船である雪龍は，北極点の真上を通っ 
て帰りました。中国による北極進出につい て，ロシアはかなり気にしています。

ウクライナ危機後のロシアの対中アプロー チは，ご承知のと拈り，クリミア編入演説で, ロシアに対して理解を示した中国，インドに 謝意を表明しました。そして，4月18日の 国民とのテレビ対話で，中露関係は歴史上最 高水準にあるが，軍事同盟にはなり得ないと プーチンは発言しています。プーチンは，両 国関係は歴史的最高水準にはあるが，軍事同 盟にはならないといらことをワンセットで何 度も言っています。

確かに, クリミア編入によって，ロシアが 国際社会から批判を受け，欧米と対立を深め ると，政治的には中国に接近する姿勢が強ま るといらことは間違いありません。中露首脳 会談が 5 月に上海で行われたとき，二人は握 手し，さらに上海では 3 回目の合同海軍演習 が行われたときは，その開幕式に参加しまし た。

中露首脳会談や今回の共同声明をどのよう に分析していくか。これも外交文書の単なる 文言であり，深い意味がないと言われたらそ れまでですが，中露の言う「核心的利益の相互 支持」というロシア語訳は微妙に変わってい ます。2010年には, коренные интересы でし たが，2012年には，ключевые вопросыに変 わり，また今年からは，коренные интересы に戻っています。

この辺には，確かに中国への配慮も見充末 す。中国とロシアの言う「核心的利益」は何 を意味しているのかといらことに関しては， 明確な共通認識はないと思いますが，このよ らな文言を見ていても，今回は確かにロシア が中国に配慮している感じはします。

ご承知のと抢り, 今回の中露首脳会談では, 2018 年から 30 年間にわたって天然ガスを供 給することが合意されました。これによって， ウクライナ危機後, 中露がさらに接近してい るように見觉ますが，ここでもら一つ注目し
なければいけないのは, 武器輸出の合意は今 回も見送られたといらことです。

スホイ 35 戦闘機 24 機とラーダ級潜水艦 4 隻の武器輸出は, 2012 年末の中露の政府間 枠組み合意によって決まっています。現在は, 最後の条件交渉を行っているわけです。確か に，今回の中露首脳会談で，この軍事技術協 力, 武器輸出が合意されると, 中露が蜜月だ といら政治的プレイアップができて一番良 かったのですが，今回もこれは実現できな かったのです。

そして, 中露首脳会談と同じタイミングで 行われた 3 回目の演習も, 軍事的にはとれほ ど注目するところはなかったといら気がしま す。今回，シルクロード経済協力ベルト構想 は, 中露共同声明の中に入っています。その 中には,「中国がロシアの利益を考慮したい と考えていることをロシアは大いに評価す る」と書いてあります。

これは, ロシアが中国に,「ロシアの利益 を考慮してほしい」と言っているように聞こ えます。つまり「シルクロード経済協力ベル 卜構想」では，ロシアが，なるべく外国の影 響が及ばないでほしいと思っている地域に， 中国が国家的な意図を持って公式的に入ると 宣言しているわけです。そして，もらすでに ウクライナまで中国は進出しているのです。 これに関しては, ロシアの利益も少し考慮し てほしい，そうしてもらえるとありがたい， それは高く評価するといらことが，今回の共 同声明の中に記されているのです。

さらに，ロシアの対中警戒論も高まってい ます。一部の有識者は, 昔はタブーであった ロシア脅威論をはっきりと言らようになって います。

例えば，カーシンという軍事専門家は，口 シア政府関係者にとって公の場で中国脅威論 に言及することはタブーだが，ロシアが取る すべての予防措置は，ロシアの主権と領土の 一体性に対する中国からの潜在的な脅威と関 
連していると言っています。そして，フラム チュヒンといら対中警戒論で有名な軍事専門 家は, 中露首脳会談の前に, 軽々に中国に武 器輸出をするのはどらかといらことを独立軍 事評論の紙上などで語っています。そして, このような対中脅威論は強まっているという ことです。

極東に打けるロシア軍の動きを見ている と, オホーツク海や極東では, ソ連崩壊後最 大級と呼ばれるような大規模な軍事演習が, 今年も含め，行われています。ただ，今まで のようにすべてが対日，対米かといらと，明 らかに中国を視野に入れたものに変化してい ます。中国に関しても，内陸の話ではなく， 北のほうにも海洋進出があるのではないかと いうことで，北方領土の軍事演習も含め，今 年の夏に行われた演習の全体を総括すると, チュコト半島, カムチャツカ半島, そして千 島列島あたりの防衛ラインを重視していると 評価されるわけです。

気になる来年の第一次世界大戦 70 周年記 念行事は, 2 月のソチの会談で, 習近平がプー チンに呼びかけたものです。プーチンはその 場では即答せず，ウクライナ危機後の 5 月の 中露首脳会談でそれを受けました。ただ，中 露共同声明には,「ドイッのファシズムと日 本軍国主義に対する戦勝 70 周年」と書かれ ています。ロシアは, 当然ドイッに重きを置 いています。従って，今のところ対日牽制と いら意味では，完全に中国に歩調を合わせて 共闘するというところまではまだ踏久切って いないよらです。そのため, プーチン大統領 の秋の訪日であるとか，5月の共同通信の記 者会見でも，領土交渉で 4 島を対象とすると か，日本に期待を持たせるよらなこともプー チン大統領は発言しているわけです。

次に，日露関係への影響です。これは言わ ずもがなですが，日本も 4 回目の制裁に入っ ています。クリミア編入，マレーシア機の事 故, ロシア軍の事実上の東部介入により, 日
本も欧米に合わせて，制裁を科していく。も ちろん内容は欧米とはだいぶ違いますが，そ の分, 日露関係では独自路線を取る余地がだ んだん狭まってきている状況です。

このように, 今までは, ウクライナ問題が 日露関係に直結するとは全く思っていなかっ たわけですが，今後は，東部も含めた，さら なるウクライナ危機による欧米とロシアとの 関係が，日本の対口政策に直結した問題に なってくると思われます。そして，そのよう な観点から， ウクライナ東部を見ていかなけ ればいけない状況が続いているのです。

最後は, 結論と問題提起です。ウクライナ 危機は，ロシアに影響圏的発想があるという ことを示したといらのが私の理解です。これ はよくロシアの軍人が言うことですが，ロシ アの影響圏といらのは, 地上部分と洋上の部 分がある。そして，この両方に入り込んでい るのは中国だけであると。しかし当然, 地上 の NATO 拡大といらところに関しては, 欧 米といらことになります。

ウクライナ危機以降, ロシアは対中依存を 強めています。しかし，そのまま依存をし続 けるといらことはあるのだろらか。やはり日 本などとの外交バランス，アジアの他の国と の関係の余地は残しておくことが，ロシアに とっては重要であると思います。そこを完全 に切って，中国に接近してしまうのか。もち ろん, 日本がさらに制裁を行えば, 中国に寄 り添って一緒に日本を批判するかもしれない といら政治的ニュアンスをロシアは示してい ますが，これがそのまま突っ走っていくのか どらかは，もら少し見ていかなければいけな いと思っています。

志摩 皆さん，ご協力ありがとうございまし た。今後の予定ですが，まず最初に，4人ほ どからご質問をいただき，その後，各 4 名の パネラーのかたがたに，5分程度のコメント をいただきます。そして，残った時間を活用 
して，フロアのほうに戻したいと思っていま す。4 人以上の手が挙がっていますが，最初 に, 斎藤先生, 上野先生, 3 人目, 4 人目々 いらことで，こちら側は後半戦で抔願い致し ます。よろしくご協力を打願い致します。

\section{斎藤元秀（中央大学政策文化総合研究所）}

斎藤と申します。きょうの 4 名のご報告は, いずれも力作で, 非常に刺激的でありました。

兵頭先生と廣瀬先生の扮二人に質問させて いただきます。まず，兵頭先生のプログラム 報告要旨には, クリミア併合について, プー チン大統領は，中国の理解に謝意を表明した と書いてありますが，私の理解では，中国は 理解もしないし，黙っていたと思います。国 連総会に打ける採決では, インドは, クリミ ア併合に棄権しました。果たして中国の場合, 理解したといららうに言えるのでしょらか。

それから，二番目は，中国とロシアの対日 共闘は，プーチン大統領が共闘にあまり乗っ てこないといらことはご分析のと扬りです が，そもそも最初に言ったのはプーチンのほ らだったと思います。プーチンが最初に言い 出して, 中国の反応を試したといらことだっ たと思います。

三番目は，中国とウクライナの友好協力条 約に対して，ロシアは，締結しないように， 中国やウクライナに压力をかけたのでしょら か, それとも何も言わなかったのでしょらか。 また, 去年締結された条約は, 両国の議会で, 承認, 批准されているのでしょらか。同条約 は今でも有効でしょらか。

次は, 廣瀬先生への質問です。廣瀬先生は 世界的にも活躍されて, 優れた研究成果を出 し，きょらも素晴らしい報告でした。ウクラ イナに対するロシアの軍事介入準備の件です が，私は相当早くから準備していたと思って いますので，廣瀬先生の説に賛成です。プー チン大統領が，急に軍事作戦を検討したとい らことではないということでは一緒です。
共通点と相違点につきましては非常に上手 に書かれていますが，ロシアには，ウクライ ナの場合もグルジアの場合も, アメリカや $\mathrm{EU}$, あるいはNGO が陰謀して起こしたの ではないかといら陰謀説があり, これも共通 点に入るのではないかといら感じがします。

そして, 相違点にあるハイブリッド戦争に ついての質問です。今度のクリミア併合に対 しては, ロシア側からこのハイブリッド戦争 を仕かけたと言っていることは知っています が, いつごろからロシアがハイブリッド戦争 を検討し出したのかといらことは分かりませ ん。もし分かれば，教えてください。

最後に一点ですが, 教訓のところにあるグ ルジア紛争からの学習といらことはそのと拓 りだと思います。しかし, もっと大事なのは, オバマ大統領の失言ではないでしょらか。オ バマ大統領は, アメリカは, 武力を行使して シリアのアサド政権に対して制裁しないと言 いましたが，そうした発言が，今回のロシア によるウクライナ併合や東シナ海, 南シナ海 に拈ける，ロシアや中国の軍事行動にかなり の影響を与えたのではないかと思っていま す。しかし，国際政治にはいろいろな見方が ありますので，この考光は違らかもしれませ ん。ありがとらございました。

\section{志摩では，続けてお願いします。}

上野俊彦（上智大学）上野です。極めて単 純で簡潔な質問です。廣瀬先生が, 共通点の 2 の中で, 黒海沿岸国といら要素を挙げてい ました。それはそのと抢りなので，よく理解 できます。その下に，「不凍港としての魅力」 と書いてありますが，たとえば，グルジアな らば, バトゥミは貿易港としてのほうが重要 なのかもしれませんが，ポチとかセバストー ポリは, 日露戦争当時であればともかく, 今 日，不凍港とあえて言ら意味があるのでしょ らか。 
もら一つは，先ほど，黒海は，ロシアとト ルコの海になっているといら括話がありまし た。それはそのと挑りですが，逆に言らと， 黒海の外に出るときには, NATO 加盟国であ るトルコの狭い海峡 (ダーダネルス・ボスフォ ラス海峡）を抜けなければなりません。そう いら意味では, ロシアと NATO が緊張状態 になれば，セバストーポリにいかに立派な軍 艦があったとしても，黒海の外に出られるわ けではありません。従って，黒海の中にある 港は，あくまでも黒海の中で用いるというこ とが重要なポイントで, 不凍港といら議論は ぞの程度意味があるのかといらのが質問で す。以上です。

木村武雄 (中央大学) 中央大学非常勤講師 の木村武雄と申します。廣瀬先生に，二つ質 問させていただきます。

先ほどのご説明はよくおまとめになってあ ると思いますが，私は，スターリンの影も少 しあるのではないかと思っています。グルジ アもウクライナも, もともとは他の民族を国 境線の中に入れて，特にロシア系住民を入れ た点が特に大きいのではないかと思います。 モルドバもそらですが，スターリンはグルジ ア人ですから，グルジア人以外の民族をグル ジア共和国の中に入れたのではないかと思っ ています。しかし，確証はありません。

そして, もともとウクライナは 300 年の間, ポーランド領でしたし, 戦間期には, チェコ スロバキア領だったこともあります。また， ドネツクなどはロシア系住民が多い所でし た。クリミア半島はもともとロシア領だった 所ですが，フルシチョフの時代にウクライナ とロシアの同盟 300 年を記念して，ウクライ ナに編入したといら経緯があります。その頃 はソ連全体の中の枠組みであったと考えられ ます。

もら一つは, 先ほど, アメリカの NGO と いらご指摘がありましたが，それと重複する
かもしれませんが，カラー革命といらのは， もともと，旧連諸国の中で，民主主義と自 由選挙を旗印にアメリカの資金を基にした NGO が導火線になったともいわれています。 確か，プーチンは，陰謀説が強いといらこと で，NGOの活動を禁止したと思います。以 上の 2 点をご質問したいと思います。

松里公孝（東京大学）松里です。ご指名い ただきましたので，六鹿先生に質問したいと 思います。

六鹿先生は, いつも鮮やかにいろいろな国 際的構想を説明されますが，少し違和感があ りました。それはリソース問題で, 何か構想 があっても，それを実現するリソースが必要 です。リソースの観点からいくと, ロシアに とって，クリミアとドネックはトレードオフ の関係にあります。ですから，3月５日に，プー チンがクリミア編入しようと決めた時点で, 「ドネックとルガンスクは諦めた，かわいそ らだけれど，キエフと交渉してほしい」とい ら立場を取ったと思います。そのため，3月 18 日の編入演説でも, 弱いウクライナはわ れわれには要らないといらことも言っていま すし，5月の最初には，末澤さんも指摘され たよらに，ドネックとルガンスクに住民投票 を延期することをはっきりと提言していま す。また，9月のミンスクでの交渉でも，ル ガンスクとドネツクが欲しいものとロシアが 考えていることは全然違いました。

内戦が始まった頃は義勇兵でしたが，今は もら単一の国軍で，それには給料を払わない といけないのです。義勇兵は戦費自弁が原則 ですが，それが国軍になった。そして，学校 も病院もウクライナから切り離し, これから は自分たちで軍事・民生全部の面倒を見なけ ればいけない。ところがドネックもルガンス クも左派政権で, 徵税対象となる有産階級は 全部逃げてしまった。したがって，どこから 扣金を持ってくるかといらと, ロシアから 
持ってくるしかないのです。しかし，それは 無理です。ルガンスクやドネックがしたいと 思っていることは，打金がないロシアは絶対 に支持できません。クリミアを養らだけでも ものすごく苦労しているロシアには，それは もら無理なことです。

あと一つ思いますのは, 六鹿先生はトラン スニストリアがご専門ですが，トランスニス トリアは，打金の面では抜き取りはするわ， ネコババはするわということで，ロシアの言 らことは聞かないですが，軍事戦略的には言 らことを聞きます。なぜかというと, トラン スニストリアの軍隊は弱いからです。しかし, 軍が強いアブハジアなどはロシアの言うこと は聞かないです。カラバフもアルメニアの言 らことは聞きません。

1990 年代以来，ロシアがアブ八ジアの括 かげでどれだけ敛んできたか，アルメニアが カラバフの拉かげでどれだけ悩んできたか想 起すべきです。ノヴォロシアが独立したら， もっと大変なことになります。自動小銃だけ で 1 万人のウクライナ兵を殺した彼らが，ま ともな武器を持ったら, すごく強い軍隊にな ります。それはロシアにとって獅子身中の虫 になることは間違いありません。

したがってロシアは，ドネックとルガンス クをウクライナに返せるものなら返したいの です。基本的に，キエフと交渉しなさいとい ら立場です。もしそうでないとしたら，国境 線にNATO の基地を作られたら困るといら 一点なのだと思います。

廣瀬さんには, 少し細かい点ですが, アジャ リア危機の時点では, サーカシュヴィリとプー チンは蜜月でした。アスラン・アバシッゼも， ロシアの公用機で逃がしました。その後に南 オセチアに軍事侵攻を始めたので，そこでけ んかになったということです。アジャリアの ときは, サーカシュヴィリが前もって相談し ましたが, 南オ七チアのときは勝手にやった といらことで，プーチンは怒ったのです。
また，ベネズエラは，クレムリンが承認す るように説得したわけではなく，これはアブ ハジアが自力で説得したのです。ウゴ・チャ ヴェス大統領がクレムリンに来たときに, 「きょら，アブハジアと南オセチアを承認し ます」と言ったので, メドベージェフはびっ くりしたのです。これは，自分たちで代表団 を送って説得したのです。恐らく，これはセ ルゲイ・バブーリン人脈です。バブーリンは 下院の中南米友好委員会の長で, チャヴェス とも仲が良かったのです。バブーリンの仲介 で，直接アブハジアが交渉したということで す。少し細かい問題でした。

志摩 ありがとらございます。熱い質問が続 いて抢ります。それでは, 最大 5 分以内で, まずはいただいたコメント，質問に和答えい ただきます。

廣瀬 たくさんご質問，ご指摘，コメントを ありがとうございました。

まず，斎藤先生のご質問ですが，共通項と してアメリカの陰謀説があるのではないかと いらこと，また，それに関連して木村先生か らも，カラー革命にも同じようなアメリカの 関与があるのではないかといらご質問があり ました。

確かに，ロシアのメディアでは，アメリカ の陰謀説が常に強調されていますので，その 意味では，確かに共通点だと思います。しか し，実際にアメリカが関与したかどらかにつ いては，少なくとも私が 8 月にウクライナで いろいろと調査した限りでは, あまり根拠が ないと考えて扮ります。もちろん NGO など を通じてある程度の資金援助があったり，ま たヌーランドさんの括が盗聴されて，アメ リカの関与の根拠とされたり，という事実は ありましたが，逆に言えば，「それだけだ」 といらような括をすべてのウクライナの研 究者がされていました。他方, マイダン革命 
は，ウクライナの腐った政治に対する国民の 反感が一つになって爆発したものだというご 意見を 100 パーセント得ましたので，「直接 的」なアメリカの陰謀は考えづらいと思いま 于。

また，ロシアはいつからハイブリッド戦争 をやり始めたのかといらことですが，これは 私自身も，今非常に興味を持っているところ です。正直に言って現時点で竹答えできるこ とはなく，解答はありません。NATO も今, 検討中ということです。しかし，これは精鋭 部隊がなければできないことで，グルジア紛 争のときには精鋭部隊はなかったわけですか ら，少なくとも 2008 年以降だということだ けは確実に言えると思います。

また, グルジア紛争からの学習に加えて, シリアのインパクトがあったのではないかと いうご指摘ですが，それはもちろんそうだと 思います。それに限らず，昨年の時点で，シ リアの問題をめぐっては, 空爆を回避させた ことで国際政治的にプーチンが上位に立った 事実もありました。また，アメリカがすでに 世界の警察官を辞めるといら発言をしたこと からも，相対的なアメリカの弱さが大きく働 いたのは間違いないと思います。

上野先生のご指摘も，もっともだと思いま す。確かに, 昔は不凍港ということは重要だっ たはずですが，現在においては，単に黒海の 中での国際政治として捉え，かつNATOの 影響力をより低下させるために，黒海の拠点 を重要視するという見方が正しいと思いま す。

そして，木村先生が扮っしゃったスターリ ンの影ですが，これは恐らく，スターリンが， ソ連時代にソ連をらまくまとめ上げるため に，わざわざ民族を分断するような国境線を 引いたという，ソ連時代によくあった言説を 根拠に抢っしゃっているのだと思います。し かし私は，それは今回のことにはあまり関係 ないよらな気がします。特にスターリンの国
境策定についてはソ連解体後に，コンピュー ター分析を用いた研究などにより, ソ連の民 族構成があまりに複雑であったことから，陰 謀説は立証できないといら論文も出ています ので，そこに関連付けてしまらのはやや短絡 的だと思います。

また，松里先生のご指摘は非常に勉強にな りました。ありがとらございました。以上です。

六鹿 松里先生，ご指摘をありがとうござい ました。報告時間がもらあと2，3 分あれば， ウクライナ危機の欧州国際秩序への影響 3 の ところで，次のようなことを言うつもりでし た。先生のご指摘どおり, リソースの問題は 重要です。私がそこで申しあげたかったこと は，価值をめぐる対立は今後も激しさを増し ていき, 西側の対露経済制裁やロシアの軍事 費増大に加え，トランスニストリア，南オ七 チア，アブハジア支援以外にクリミア領有の 費用がかさむとなると， ロシア経済の停滞は 避けられません。他方, ウクライナ危機が始 まる前の世論調査では，ロシア国民の拉よそ 半数は自国の国際的地位よりも自分達の生活 水準の方が重要であると答えています。した がって, 経済状況が悪化し生活水準が低下寸 ると，ロシア社会に，なぜ自分達と関係の希 薄な人たちを支援しなければならないのかと いった雾囲気が釀成されていくのではないで しょらか。その場合，マスメディアによる欧 米批判や外的脅威論などを介した国民動員態 勢が，果たしてどこまでもつのかといった疑 問がわいてきます。

さらに, 今のロシアは, プーチン大統領が 合理的な判断を下せるような状況にあるの か，といった問題も考える必要があります。 本日の第一部の報告でご指摘がありましたよ らに，ロシアの中には大別して三つの政治勢 力があり，エリッィン政権は当初民主派に基 盤を置いていましたが，やがて現実派（リア リスト）勢力に依拠するようになりました。 
他方，プーチン大統領は最初は現実派勢力に 権力基盤を置いていましたが，2012 年に大 統領ポストに返り咲く頃には，権力基盤の重 点を民族主義勢力へと移していますので，彼 が合理的な判断を下すことができるのかどう か, 極めて難しい状況にあると思います。こ の点につきまして, ロシアの専門家の先生方 に扔尋礼したいと思います。

松里先生がグルジアについて括話になられ ましたことについて，グルジアの元外相から 興味深い話を聞いたことがあります。2004年 はじめに大統領に就任したサーカシュヴィリ の最初の訪問先がロシアだったことはご記憶 にあると思いますが，彼とプーチン大統領は クレムリンの執務室で二人だけで会談し, 上 機嫌で出てきたそうです。アジャリアは問題 ないが，南オセチアについては，ロシアの関 連諸機関の調整に時間がかかるのでそれまで 待って欲しいと，プーチンはサーカシュヴィ リに述べたそらです。ところが, サーカシュ ヴィリはその約束を守らず，南オセチアの領 土回復に乗り出しました。プーチン大統領が あるジャーナリストに語ったところでは，世 の中には三種類の人間が存在し，その内敵と 友人は問題ないが，自分を裏切った友人だけ は断じて許すことができないとのことです。 南オ七チア侵攻後のロシアとグルジアの急速 な関係悪化と, 2008 年夏のロシア軍による 首都トビリシをめがけた大規模な軍事攻撃の 原因は，この辺りにあるのかもしれません。

兵頭 ご質問ありがとうございます。まず， 上野先生がご指摘されたセバストーポリの軍 事的価值の点ですが，私も先生が招っしゃる と扣り，軍港としては，ないよりもあったほ らがいいといらことは当然ですが，ただ， NATO を牽制できる軍事基地といらのは言い 過ぎではないかと思います。

やはり, 通常戦力では, 基本的にはロシアが 劣勢なので，本当に軍事的に牽制しょうと思
らと，核のところまで踏み込まざるを得ない わけです。今回, イギリスでNATOのサミッ トがありましたが，NATO も，何かあったら ポーランドやバルト三国に部隊を送るなど， ロシアに当てた政策に転換するような姿勢を 見せています。それにロシアが反応して, 現 行の軍事ドクトリンを年末までに改正すると 言っています。そらなると, 多分それは, 核戦 力の強化以外にはないのだろらと思います。

そして，斎藤先生からの三つの質問につい てです。まず，クリミア編入の話です。プー チンが演説で何と言っているかというと，口 シアのクリミア問題を理解してくれたすべて の国と言った後に中国が出てくる。これは, ご承知のと打り, 中国自身は, はっきり理解 したといら態度はとってないわけですから， そこはプーチンの解釈を演説に入れていると いらことだろらと思います。私のレジュメで は，そのような表現でプーチンが演説したと 言っているだけで，中国がロシアの行動を理 解をしたといら客観的事実を言っているわけ ではありません。

また，いつから中露が対日共闘の話をし出 したか，そしてそれはプーチンが言い始めた のではないかというご指摘でしたが，これは ちょっと難しいことです。そのように枑い に共闘で第三国を牽制すると公言することは 非常にレアなケースで, 非公式な場で, どち らが言い出したかということは当然さかのぼ ることはできないわけです。

少なくとも, 中国とロシアの北方領土と尖 閣問題で相互支持するといら話は，中国側か ら持ちかけられたのではないかといら幅広い 観測が出たのは，私が知る限りでは，2012 年 8 月 20 日にモスクワで開かれた, 第 7 回 中露戦略安保会議に颃いての出来事です。

中国の戴秉国国務委員 - 外交担当副首相級 が, パトルシェフ安全保障会議書記に対して, 北方領土と尖閣の共同歩調を持ちかけたが, パトルシェフが応じなかったといら話です。 
これはロシア側から出た観測です。これは観 測でしかないため，これ以前のプーチンの動 きについては，私自身も承知していません。 したがって，もしプーチンが中国よりも前に それを公言していたといら事実があれば，教 えていただきたいと思います。

最後に, 中国・ウクライナの友好協力条約 の議会承認に関しては, 実はよく分からない, 不明であるといらのが定説です。ヤヌコ ヴィッチの政権はその後崩壊したわけですの で，ウクライナ側は多分批准できてないと思 います。そして，中国に関しても，私の知る 限り，確認されていないといらことです。

志摩 それでは，後半の質問に入ります。ま ずこちらから 4 名で, 時間に余裕がありまし たら，袴田先生に回らせていただきます。そ れでは，手短にご質問をお願い致します。

羽場久美子（青山学院大学）羽場と申しま す。メインは六鹿先生ですが，廣瀬さんにも 打伺いいたします。全体としてウクライナを めぐりロシア対 EU・NATO の対立関係とい ら問題に対し，いくつかの疑問があります。 変化が現れているのではないか，ということ です。

特に, 日本では, ウクライナの革命は欧米 寄り，東部はロシア寄りという，二項対立的 な形で論じられていますが，果たしてそらな のか。特に 6 月， 7 月， 8 月， 9 月の過程の 中で，EUとアメリカの戦略の間に，ずれが 出てきているのではないか。

それに関連して三点伺います。一つは, メ ルケルが 6 月から 7 月にかけて, プーチンに 対し積極的に有和政策，仲介政策を取ってい るといらことです。そしてこの 8 月末から 9 月の頭に, 次期欧州理事会の議長が, ポーラ ンドのトゥスクになりました。これは結構驚 くべき人事です。トゥスクは現首相ですが, ロシア有和派といわれています。な拉かつ
ポーランド国内では，EUの外交担当もささ やかれていた親米家のシコロスキ外相が抑え られるといら形が取られています。ポーラン ド，アメリカと EUがウクライナを支持する といら関係は，とりわけこの夏からは，EU， 特にドイッが，積極的なウクライナ支持を諦 め始めているのではないかと思われます。

二点目はそれに関連して，革命後のウクラ イナに打ける EU連合協定の延期の問題で す。六鹿さん，廣瀬さん共に，ロシアの圧力 がある，またそれはウクライナの要請であっ たと言われました。しかしこの9月に，下斗 米先生と現地に行かせていただいたときのイ ンタビューではウクライナの元首相で産業家 企業家同盟代表キーナフが，これは EUの提 案であると言っていました。つまり，EUは， ヤルタ・ヨーロッパ戦略会合（YES）の中で も， ウクライナはルール・オブ・ロー（法の 支配）を守れ，腐敗と污職を一掃せよ，デモ クラシーとリベラリズムを実現せよ，という ことを強く要求しています。ここはかなり, ウクライナの熱意と EU の及び腰との間の乘 離が見られます。

EU は経済同盟なので，経済に沶いてウク ライナに利が取れないとすると，ロシアとの エネルギー関係のほうが重要なのではない か。これも二者択一ではなく, 両にらみでは ありますが，そのようなところで EU のイン タレストとしてロシアへの有和政策が始まっ ているのではないかということです ${ }^{(1)}$ 。

三点目は，イスラエルとの関係です。4月 にイスラエルに行ってきましたが，イスラエ ルではロシアとの関係を非常に強めていると 言っていました。また，クリミアのユダヤ人 が，クリミアのウクライナ編入後イスラエル に随分移住しているといわれています。現在 のイスラェルの人口の 10 パーセントは旧ロ

(1) 発言者註：その後 11 月末，EUは，ロシアと エネルギー問題でウクライナの頭越しに妥結 を行った。 
シアから入ってきていて，ロシア語のテレビ や新聞もさかんです。今回のクリミアの問題 に対して，イスラエルは中立ないしは潜在的 ロシア支持といらところもあるようです。イ スラエル・ユダヤ人がアメリカに対してもロ シアとのブリッジになっているといらことも 言われています。

これらについてどのように抢考えになるの かを，教えていただきたいと思います。あり がとらございました。

志摩では，打願いします。

岩田昌征（元千葉大学）岩田と申します。 質問は三つありましたが，一つは羽場先生と 重なってしまったため，二つになります。

一つは, このあいだ暗殺されたサシコ・ビー ルィ（アレクサンドル・ムズィチコの愛称） といら方は，チェチェンでドゥダェフ大統領 警護部隊の隊員でした。ウクライナの民族主 義者とチェチェンの民族主義者との連帯, 共 闘は非常に強固だったわけですが，もしこの ままウクライナの情勢で，ロシアとの関係が 修復されなかったときは, ロシア内部で今は 収まっているチェチェン等々への影響が将来 考号れるか, といらことが一つの問題です。

二つ目は，一番大きな問題です。大西さん が言われたようにロシアは, 北極海, 北の防 衛を考え出しました。これは当然のことです。 ロシアは, 今まで, 西と東, 打よび南の防衛 だけを考えていて，北は，全然考えなくても 済む所だったわけです。

ところが, 温暖化がここまで進み, 海岸線 が氷の海岸線ではなく, 水の海岸線になると いらことは，つまりロシアの防衛線を非常に 長く引かなければならない事態がやがて来る のではないか。これは温暖化の進展によりま すが，もしそうなった場合，ブラジルにせよ， 中国にせよ，アメリカにせよ，世界の大国に は, 国を守るための人口は十分あるわけです。
ところが，世界第一の地域的大国でありなが ら 1 億 4000 万の人口しかないロシアが，そ らなったときに自分の国を守れるのか。

恐らく, 中国やブラジル，アメリカはそら いう点では脆弱ではないけれど, ロシアは極 めて脆弱になる。ということで, 大西さんが 指摘されたことは, 将来ロシアの縮小, 解体 に通じるかもしれない大きな問題ではなかろ らか，と思いますが，いかがでしょらか。

木村崇（元京都大学） 私が聞きたかったこ とを上野さんが招っしゃったので, 完全に上 野さんと意見が一致していますが，それに対 して兵頭さんがこうコメントされました。つ まり, 廣瀬さんの報告の中の, 共通点 2 のと ころ，NATO を牽制できる軍事基地を維持し たいロシアといら所については, 少なくとも, 上野さんも兵頭さんも, セバストーポリが あっても, 核兵器を考える以外にはNATOを 率制できる要素はないといら技考えでした。

そらすると、プーチンがクリミアの国取り を決意した要素の中には，セバストーポリが ロシアの運命にとって, 致命的に重要なもの ではないといら考党があったのかどらかとい らことを兵頭さんに和聞きしたいと思います。

村井淳（関西外国語大学）村井と申します。 特に兵頭先生に和聞きしたいと思います。口 シアが中国に武器を売るという話は成立しな いということでしたが，私が聞いた話でも， 中国は武器のサンプルは買らけれど, その後 は無断でコピー製品を作るといらことがあり ました。それを基にすると，一般的に，ロシ アは中国に対してある程度の不信感を抱いて はいるけれど, 共通の利益があるところでは 手を握らざるを得ないといらことがあるのだ と思います。そこで，もしそのような不信感 があるとすれば，それはどの程度のものであ るのか, そして，どのよらなことが手を握る 要素になってくるのでしょらか。 
ロシアが外国に提供できる地下資源以外の 工業技術は，武器と宇宙技術ぐらいだと思い ますので，これはロシアにとっては大切な虎 の子だと思いますが，それを基にして，特に 中国に対する不信感がどの程度のものかとい うことを扬聞きしたいと思います。

志摩 ありがとうございます。先ほど，手を 挙げていただいた袴田先生にマイクが行って いると思います。

袴田茂樹（新潟県立大学）時間の関係で, 私からは, 質問といら形ではなく, コメント だけにさせていただきます。最初に，セバス トーポリ軍港の意義ですが，今日ロシアがそ れに拘るのは, 不凍港確保, あるいは兵頭さ んが問題にされた NATO に対抗するといら 意識よりも, ロシア側には, ウクライナ, あ るいはウクライナ南部, クリミアが, 米軍や NATO の支配下になるということに対する一 種の恐怖心があると思います。ウクライナ地 域に, NATO の軍事基地やミサイル基地がで き，またセバストーポリや黒海でのロシア軍 の行動も大きく制限されるのではないかとい ら恐怖心，それが最大の動機だと思います。

このセッションの全体の印象について述べ ます。ウクライナの併合にしても, ウクライ ナ東部の現在の状況にしても, これは極めて 深刻な国際法侵害の問題ですが，この会で非 常に強く感じたのは, 国際法的な問題がほと んぞ提起されず， ウクライナ問題が歴史的, 宗教的, 政治力学的, あるいは軍事的な問題 という形でいろいろと論じられていたという ことです。

これに対しては, 二つの解釈ができると思 います。一つは，ロシア・東欧学会の皆さん の多くが，国際法は大した力を持っていない とリアリスト的に考觉るようになられたとい ら解釈です。もら一つは, 皆さんがロシアの 国際法侵害に関しては比較的寛容だという解
釈です。しかし私は，南シナ海，東シナ海問 題なども視野に入れてグローバルに考える と, 国際法的な問題が，本来は一番深刻な問 題だと思います。世界の 100 カ国がクリミア 併合に反対したのも，単に米国などの政治的 圧力ゆえではなく，国際法の根幹が摇らいで いるからです。それが全く提起されなかった ことに，強い印象を受けました。以上です。

志摩 ありがとうございます。それでは，恐 れ入りますが，2，3 分ずつ扔願い致します。

廣瀬 ご質問，コメントをいろいろありがと らございました。時間がないので，簡潔に答 えさせていただきます。

まず，羽場先生のご指摘についてです。夏 から秋にかけて，欧州のウクライナに対する 姿勢が変わってきたのではないかといらこと ですが，私は，もともとアメリカと EUの間 には激しい「ずれ」があったと思っています。 逆に, マレーシア機撃墜事件で，一時接近し た両者が，また元の趨勢に戻ったというと理 解しています。

また, イスラエルの問題は, グルジア紛争 の時に起きたことを考えると参考になると思 います。もともとグルジアはイスラエルから たくさん武器を買っていて，イスラエルとア メリカの武器によって軍隊を近代化させてい たといら経緯がありました。そして，グルジ アの当時の首脳陣にも, ユダヤ系の人が結構 いました。他方，グルジア紛争後に，ロシア が軍の近代化を必須と考光, 初めて, NATO 加盟国であるフランスからミストラル級艦の 購入について話を進めたり，また，イスラエ ルからは無人偵察機を購入したりしました。 その際イスラエルは，国益を優先するという ことで, その後グルジアとの兵器の取引はや めて，ロシアを選んでいます。ですから，ウ クライナについても，その文脈で考兄られる のではないかと思っています。 
岩田先生のご指摘は，チェチェンの過激派 がウクライナにも入っている，それがチェ チェンに影響するかといらことでしたが，そ もとも現在のチェチェンは, 決して一枚岩で はありません。特に, 現在のチェチェンは, プーチンとはかなり息が合うカディーロフが 強権政治を敷いている状況です。逆に，過激 派はみんなチェチェンを出て，その他の北 コーカサス地域で暗躍しているといら事実が あります。ですから，北コーカサス全体の不 安定化には影響すると思いますが，むしろ チェチェンへの影響に限って言えば，それほ ど大きな影響はないかもしれません。

国際法の問題ですが，今回，国際法の問題 には全く言及しませんでしたが，私も大変重 要だと考えています。今回のクリミア編入の みをとってみても, 非常に多くの国際法抢よ び国際間条約，さらにウクライナの国内法へ の違反が見られます。これについては,『法学 教室』7月号に拙稿を出しておりますので，も しょろしければ, 扔読みください。以上です。

六鹿 羽場先生，どらもありがとうございま す。私の報告は先生がご指摘されたよらな論 調に沿っていたと思いますが，簡潔に繰り返 します。一つは， 7 月 2 日の 4 カ国ベルリン 外相会議に打ける独露協調, ここでは恐らく ドイッがウクライナに圧力をかけたと思われ ます。二つ目は，ポロシェンコが「国際社会 は和平を望んでいる」としてミンスク和平協 議を受け入れた背景に，アメリカとドイッが ウクライナへの武器供与を拒んだことがあり ました。オバマ大統領は, 非 NATO 加盟国 のウクライナに同盟国の地位を与えるという 要請も断りましたし, NATO ウェールズ・サ ミットがグルジア NATO 加盟行動計画 （MAP）資格を与えないなど，ロシアへの配 慮が続いているわけです。

しかし，私は羽場先生が仰るような有和政 策といら言葉は使いたくありません。NATO
事務総長のラスムッセンは対露有和政策を否 定していますし，ドイッはもともとロシア第 一主義 (Russia first) です。加えて, 対露経済 関係は, EUとアメリカでは余りにも違います し，ロシアの経済ロビーや利益集団が各国に いるわけですから，プーチン氏はそのよらな いろいろな手段を使えるわけです。したがっ て，ドイッがロシアに協調的な手段をとるの はごく自然なことで，現段階で対露有和政策 と判断するのは早計ではないかと思います。

大西 岩田先生，ぞうもありがとうございま す。私はロシアの専門家ではないので，先生 のご質問は，恐らく兵頭先生のほうが適切に 扮答えになられると思いますが，私のほらか ら簡単に一言だけ申し上げます。

先生が拈っしゃるように，まさにロシアが シベリアに配備をするようになれば，非常に 大きな財政負担になることは明白です。ただ， 私が関心を持っていることは，まずその配備 に至る前の段階です。今，少しずつ，配備を するという発言が出て, シベリアの上のほう の北極海の島では軍事演習をやったり，ムル マンスクに旅団を作ったり，新シベリア島で 部隊を作ったり，今まで使われていなかった 旧ソ連時代の飛行場に再びテコ入れしたりと いう動きはあります。

ただ，出されている発言の多くが本当に実 現されるかどらかは非常に疑問です。また， 実現されたとしても，それをどこまで維持で きるかも非常に疑問です。したがって私も， ロシアがシベリアでどこまで配備できるかと いらことについては，非常に疑問を持ってい ます。

兵頭 大西さんへいただいたご質問に付け加 えて和答えします。最近，ロシアの安全保障 問題に関して向こうの政府関係者や軍関係者 と話をすると，北極の話ばかりになります。 そのため，いろいろな国際会議で，大西さん 
と一緒になることが多いのです。実際に，彼 らの妄想，パーセプションは，ものすごく高 まっています。将来的に, 水が解けていくの は趨勢なので，時間とともに，北極を何とか しなければいけないと思っているのはそのと 抢りだと思います。

ただ，自国で全部できるかというと，それ は大変だといらことも分かっていると思いま す。そうすると，ぞの国とどう協力してくか といら話になるのです。大西さんのご指摘も あったように，今，ウクライナ問題で，ノル ウェーやアメリカとの北極をめぐる安全保障 協力がストップしかかっているので，沿岸国 と協力しながら何とかやりたいといら動きが すでに見られています。

私が理解する範囲では, 実は日本とも, で きれば何か北極で，協力したいと考光ている のではないかと思います。なぜかといらと， 北極といらのは北極海だけではありません。 アジアからのゲートウェイは, 日本海, オホー ック海, 千島列島もあるのです。そうすると, ノルウェー, アメリカだけではなく, 日本と の協力にも頼らざるを得ないのです。

そのため, 最近の日露関係の隠れたキー ワードに, 北極の資源, 安全保障協力があり ます。その背景には，北極の問題があるので はないかと思います。

また，木村先生の，セバストーポリが死活 的に重要だから，それを守るためにクリミア を編入したのかといらことについては，多分 それ以外の要素のほらがプライオリティーが 高いと思います。もちろん，これも否定はし ませんが,やはり,グルジアの場合は, NATO 加盟の実現可能性を低下させるといら ことで, 南オセチア，アブハジアの独立を承
認しました。そして，今回はクリミアです。 ただ，クリミアは，承認だけではなく，編入 まで行ってしまったということだと思いま す。

最後に, 村井先生から, ロシアの対中不信 といら話がありました。私の結論では，これ は増えています。ただ，これもロシアの主観 といらか, パーセプションの問題で第三者が 定量的に証明するのはなかなか難しいことで す。あえて言わせていただくと, 軍事安全保 障, 軍事合理的な分野でも, 中国のファクター を除いては説明しにくい現象が増えていると いうことは事実です。

たとえば，ロシアが中距離核ミサイルを持 ちたいといら話，あるいは，先ほど报話しし たような軍事演習に関しても，中国を除いて 説明できないものが増えています。その分野 に扔いては，少なくとも中国ファクターがあ るのではないかと考えています。

志摩 ほぼ 2 時間 15 分, 予定ど和りの時間 で終わることができました。皆さん，ご協力 ぞらもありがとうございます。多様な視点, 問題提起，そして多くのコメントをいただき ましたことを，パネラー，フロアの皆さまが たに感謝致します。

私は，バルトの研究をしているので，きょ らの括話に加えて，これからはさらにドイッ とロシアの関係などを勉強する機会があると 大変られしく思います。これからの懇親会で, ぜひとも今後の議論を続けていただければと 思います。本日はまことにありがとうござい ました。 